\title{
Planning and development of Costa Rica water resources: current status and perspectives
}

\author{
Planificación y desarrollo de los recursos de agua \\ de Costa Rica: situación actual y perspectivas
}

Isabel Guzmán-Arias'

Julio C. Calvo-Alvarado²

Fecha de recepción: 26 de marzo del 2013

Fecha de aprobación: 4 de agosto del 2013

Guzmán-Arias, l; Calvo-Alvarado, J. Planning and development of Costa Rica water resources: current status and perspectives. Tecnología en Marcha. Vol. 26, № 4. Pág 52-63

Escuela de Ingeniería Agrícola, Instituto Tecnológico de Costa Rica, Cartago-Costa Rica. Correo: iguzman@itcr.ac.cr.

2 Escuela de Ingeniería Forestal, Instituto Tecnológico de Costa Rica, Cartago-Costa Rica. Correo: jucalvo@itcr.ac.cr. 


\section{Palabras clave}

Recursos Hídricos; Planificación; Balance Hídrico; Costa Rica.

\section{Resumen}

En este artículo se describe la situación actual de disponibilidad y demanda de recursos hídricos de Costa Rica, así como la evolución del marco legal e institucional para la planificación y la gestión.

Costa Rica tiene $51100 \mathrm{~km}^{2}$ de superficie y contiene 34 cuencas nacionales. La vertiente del Caribe representa el 46,4\% del país, mientras que la vertiente del Pacífico corresponde a 53,6\%. Costa Rica también tiene el 34,3\% del territorio en dos cuencas transfronterizas, Rio San Juan con Nicaragua y el Río Sixaola en Panamá.

En el territorio hay 12 embalses hidroeléctricos que suman un total de $95 \mathrm{~km}^{2}$ de superficie y 217 cuerpos de agua naturales que cubren $40,5 \mathrm{~km}^{2}$ de superficie. El balance hídrico anual promedio a nivel nacional para el período 1970-2002 es la siguiente: $3297 \mathrm{~mm}$ de precipitación, 2.215 mm de escorrentía y $996 \mathrm{~mm}$ de evapotranspiración. Se estima que el suministro potencial agua de Costa Rica es equivalente a $113 \mathrm{~km}^{3}$ de escorrentía que corresponde para el 2005 a una disponibilidad de agua per cápita de $26221 \mathrm{~m}^{3} /$ persona/año. El volumen utilizable aguas subterráneas a nivel nacional se estima en I I $\mathrm{km}^{3}$ de agua, lo que resulta en un flujo sostenible de $350 \mathrm{~m}^{3} / \mathrm{s}$.

Se estima que en 2005, las extracciones de agua para diversos usos ascendieron a unos $22 \mathrm{~km}^{3}$ o el $20 \%$ del volumen de agua disponible. La extracción de agua para la generación de energía hydroeléctrica representó el $72 \%$ del total, seguido de la agricultura con un $21,2 \%$. El uso para el consumo humano, el turismo, la industria y la agroindustria representó el 6,8\% del total y un $88 \%$ de este volumen proviene de fuentes subterráneas, lo que destaca la importancia estratégica de la protección y la explotación sostenible de los acuíferos del país. Las proyecciones del uso del agua para el año 2020 para todos los usos alcanzan a $37,87 \mathrm{~km}^{3}$, equivalentes a más del $33 \%$ de la disponibilidad total de los recursos hídricos del país.

Los dos problemas principales son la ausencia de una única institución con plena responsabilidad en la planificación y la gestión de los recursos hídricos y que la ley actual del agua es obsoleta. Por lo Tanto, es urgente adoptar una nueva ley sobre el agua con una visión moderna para conducir la reorganización del sector, redefinir un nuevo esquema de tarifas de agua para financiar la investigación, el desarrollo, la planificación y la conservación del recurso. Sin esta herramienta legal, los recursos hídricos del país seguirán siendo sobreexplotados, creando desequilibrios y conflictos entre sectores sociales y productivos, el aumento de vulnerabilidad a la contaminación y los riesgos para la salud pública.

\section{Key Words}

Water Resources; Planning; Water Balance; Costa Rica.

\section{Abstract}

This article describes the current status of water resources availability and demand in Costa Rica as well as the evolution of legal and institutional framework in the planning and management of this valuable natural resource.

Costa Rica, in its $51100 \mathrm{~km}^{2}$ of area, contains 34 national watersheds. The Caribbean slope equal to $46,4 \%$ of the country, while the Pacific slope to $53,6 \%$. Costa Rica also has $34,3 \%$ of the territory in two transboundary basins; Rio San Juan with Nicaragua and Rio Sixaola with Panama. There are 12 hydroelectrical reservoirs which total $95 \mathrm{~km}^{2}$ of area and 217 natural water bodies with $40,5 \mathrm{~km}^{2}$ of area. The nationwide average annual water balance for the period 1970-2002 is: $3297 \mathrm{~mm}$ of rainfall, $2215 \mathrm{~mm}$ of runoff and $996 \mathrm{~mm}$ of evapotranspiration. It is estimated that the potential water supply for Costa Rica is equivalent to $113 \mathrm{~km}^{3}$ of runoff and that the 2005 per capita's Water Availability equals $26221 \mathrm{~m}^{3} /$ person/year. The nationwide groundwater usable volume is estimated to be $11 \mathrm{~km}^{3}$ of water, resulting in a sustainable flow of $350 \mathrm{~m}^{3} / \mathrm{s}$.

It is estimated that in 2005, withdrawals of water for various uses totaled about $22 \mathrm{~km}^{3}$ or $20 \%$ of the volume of available water. Water withdrawals for power generation accounted for $72 \%$ of the total, followed by agriculture with $21,2 \%$. The use for human consumption, tourism, industry and agribusiness accounted for $6,8 \%$ of total removal and $88 \%$ 
of this volume comes from groundwater sources, highlighting the strategic importance of the protection and sustainable exploitation of the aquifers in the country. The water use projections for 2020 for all uses will reach $37,87 \mathrm{~km}^{3}$, equivalent to more than $33 \%$ of the total availability of water resources of the country.

The major problems are associated with the absence of a single institution with full responsibility for planning and management of water resources and that current water law is obsolete. Hence it is urgent to adopt a new water law with a modern vision to drive the reorganization of the sector, redefine a new water tariff scheme to fund research, development and resource planning and conservation. Without this legal tool, the country's water resources will continue to be overexploited, creating imbalances and conflicts between social and productive sectors, increasing the vulnerability to pollution, overused and public health risks.

\section{Introduction}

Costa Rica has favorable climatic characteristics that in conjunction with its mountainous topography make the country a rich water nation. Despite this privileged status, this resource has not been thoroughly evaluated and managed to ensure its sustainable use. Consequently, it is imperative to promote a culture of water planning and conservation to cope with current and future water demands for all users, including ecosystems needs. Therefore, it is urgent to address this issue with a renewed approach and to avoid old policies that had relied mainly in considering only water demand by neglecting problems such as water temporal and geographical availability, high water pollution, lack of waste water treatment, ecosystem demands and other important institutional and legal aspects required for an integrated water management.

This article aims to present the state of Costa Rica's water resource characteristics, availability, use and future demand, as well as, the institutional and legal management framework as a basic input to help understand the problems and develop future proposals to build long-term water resources policies and planning.

\section{Methodology}

Water resources use and demand data was extracted and projected from state agencies data bases and technical reports. Information about water resources characteristics and availability, as well as, the legal, political and administrative framework associated with water resources management and planning were obtained from publications and technical reports. Once this information was summarized, a general discussion and recommendations were provided to support efforts for developing an integrated water resources management approach.

\section{Results and discussion}

\section{Water Resources of Costa Rica}

Hydrological characteristics of Costa Rica. Costa Rica has special hydrological characteristics due to a combination of several factors. First, the country is divided longitudinally by the Talamanca, Central and Guanacaste's mountain range, dividing the country in the Caribbean and the Pacific slopes. Because of the steep terrain and the prevailing trade winds there is a strong influence of orographic precipitation (CalvoAlvarado, 1990). The northwest-southeast ridges of the Caribbean slope are rainy almost all year round by the direct influence of the northeast trade winds, active from November through March. Then between May to October throughout the country is influenced by the passage of the Intertropical Convergence Zone and by the southwest trade winds. In this way only the Pacific Slope experiences a dry season between December to April, because the humidity coming from the Northeast Tradewinds is retained on the Caribbean slope. Hence the rivers of the Caribbean slope have a plentiful flow throughout the year, while the rivers of the Pacific slope experience low flows during the dry season (Calvo-Alvarado, 1990). According to Manso et al. (2005), both temporal and spatial distribution of rainfall in Costa Rica is also modulated by changes in oceanic and weather phenomena as El Niño (warm phase) and its opposite, La Niña (cold phase), which are considered the highest expressions of climatic variability.

Availability of surface and groundwater resources. Costa Rica has $51100 \mathrm{~km}^{2}$ of area and 34 national watersheds (figure I and table I). The Caribbean slope equal to $46,4 \%$ of the country, while the Pacific slope 
to $53,6 \%$. Costa Rica also has $34,3 \%$ of the territory in two transboundary basins (Calvo-Alvarado 1990): a) The North Slope of the country shares the San Juan River basin (excluding the Lake of Nicaragua), with an area of $38500 \mathrm{~km}^{2}$, of which 36\% (I3 860 $\mathrm{km}^{2}$ ) belongs to Costa Rica and b) on the Caribbean side shared 81\% (2 $\left.336 \mathrm{~km}^{2}\right)$ the Sixaola River basin with the Republic of Panama. With regard to inland natural water bodies there are $40,5 \mathrm{~km}^{2}$ corresponding to 16 lakes, 7 ponds, I7I small lakes and 23 coastal lagoons (INCOPESCA, 2005).

According to table I, the historical annual average rainfall (1970-2002) produces a volume of $168 \mathrm{~km}^{3}$. Thirty percentage of rainwater in Costa Rica correspond to evapo-transpiration, the rest is runoff and base flow (70\%). It is estimated that the potential volume of water supply for Costa Rica is $113 \mathrm{~km}^{3}$, equivalent to $3589 \mathrm{~m}^{3} / \mathrm{s}$ of runoff. Hence the per capita's Water Availability equals $26221 \mathrm{~m}^{3} /$ person/year, assuming a population for year 2005 of 4309 400,00 inhabitants. In summary, the country's average annual water balance is: rainfall $3297 \mathrm{~mm}$, runoff $2215 \mathrm{~mm}$ and $996 \mathrm{~mm}$ evapotranspiration. This estimate has a discrepancy of $86 \mathrm{~mm}$ which is equivalent to an error of $2,6 \%$ nationwide
(UNESCO, 2007). With regard to groundwater, it is estimated that nationwide there is a usable volume of $1 \mathrm{l} \mathrm{km^{3 }}$ of water, resulting in a sustainable flow of $350 \mathrm{~m}^{3} / \mathrm{s}$ (Reynolds, 1997). Table I includes information about the annual water balance for each national watershed. Information on monthly water balances for these same watersheds is no provided in this article but this valuable data can be consulted in MINAE (2008).

Hydroelectric generation and inter-annual reservoirs. In total there are 12 hydroelectrical reservoirs with $95 \mathrm{~km}^{2}$, the largest of these are: the Lake Arenal $\left(87,7 \mathrm{~km}^{2}, \mathrm{I} 570\right.$ million of $\left.\mathrm{m}^{3}\right)$, Cachí $\left(3,23 \mathrm{~km}^{2}, 48\right.$ million of $\left.\mathrm{m}^{3}\right)$, Angostura $\left(2,56 \mathrm{~km}^{2}\right.$ and I I million of $\mathrm{m}^{3}$ ) and Pirrís $\left(\mathrm{I}, \mathrm{I} 4 \mathrm{~km}^{2}, 31\right.$ million of $\left.\mathrm{m}^{3}\right)$ (OIRSA, 2007).

Costa Rica has a useful potential of hydroelectric generation of $6663 \mathrm{MW}$ and by 2005 the country uses only I $408 \mathrm{MW}$ or $21 \%$ of the useful potential. About $82 \%$ of hydroelectric generation is produced by the Instituto Costarricense de Electricidad (ICE) with over 10 projects located throughout the country, the rest of the generation (18\%) is produced by private companies (MINAE, 2008). Accurate data on

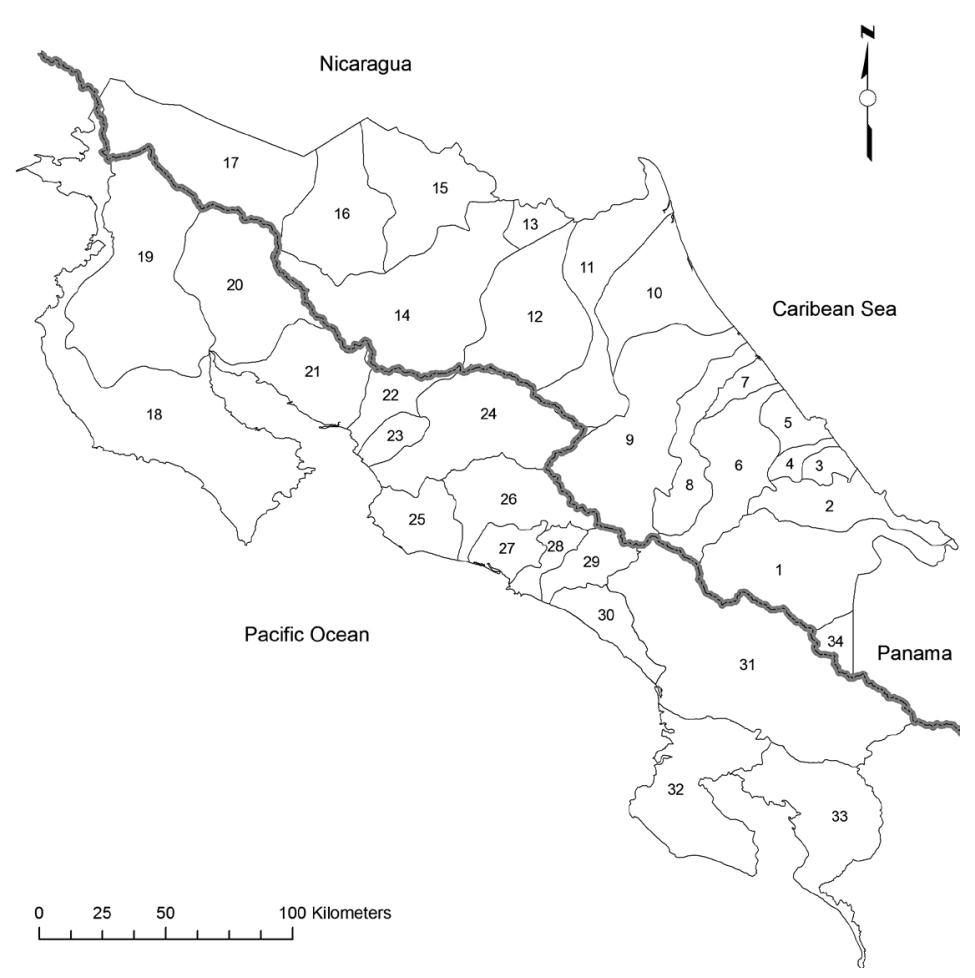

Figure I. Costa Rica National Watersheds Map and Continental Water Divide (Source: ITCR, 2004) 
how much water is turbined for hydropower generation has been difficult to obtain, but until 2005 the available information from the Department of Water and the ICE it is estimated in $501 \mathrm{~m}^{3} / \mathrm{s}$, including private generation. Projections in hydropower generation for the next 15 years are aimed at investments to generate $3200 \mathrm{MW}$ to meet growing electricity demand. The ICE is projecting to meet part of demand by expanding the capacity of current projects and with new hydroelectric projects: Reventazón (year 2015 with 300 MW, I 52 $\mathrm{m}^{3} / \mathrm{s}$ ), Diquís originally called "Boruca" (year 2018 with $623 \mathrm{MW}, 168 \mathrm{~m}^{3} / \mathrm{s}$ ), Pacuare (year 2019 with $167 \mathrm{MW}, 42 \mathrm{~m}^{3} / \mathrm{s}$ ) and Savegre (year 2020, $200 \mathrm{MW}$, $\left.45,6 \mathrm{~m}^{3} / \mathrm{s}\right)$.

Geothermic electrical generation. Up to 2005 Costa Rica generated about $150 \mathrm{GWh} /$ year of electricity using geothermal plants located along the Guanacaste Volcanic Mountain Range. In order to produce the vapor for this generation an estimated $44400 \mathrm{~m}^{3} /$ year of water is required for each GWh, resulting in an annual water demand of about 0,21 $\mathrm{m}^{3} / \mathrm{s}$ (Aguilar et al, 2004).

Irrigation for agriculture. Costa Rica has about 430 000 ha of land with potential to be irrigated and only 103000 ha have some infrastructure and are currently under irrigation using about $148 \mathrm{~m}^{3} / \mathrm{s}$. About 31 000 ha have been developed by the State and among 72000 ha by the private sector (CINPE, 2004; Cepal 2005). The largest concentration of irrigated land is in the Guanacaste Province and in the Central Pacific region. The most outstanding project under the tutelage of government (SENARA) is the Tempisque Arenal Irrigation and Drainage District (DISTRA), located in driest province of Guanacaste, utilizing water from the Lake Arenal reservoir. This district grew out from a master plan developed over 30 years ago. Initially this project was for 60000 ha, but later it was determined that the project would cover only 40000 ha. Up-to-date DISTRA has been able to provide irrigation for about 28000 ha and benefits approximately । 125 families producing mainly sugarcane, fodder, rice, and fish from 400 ha of aquaculture of Tilapia. In addition SENARA is in charge of 95 irrigation and drainage projects of small areas (PARD) distributed across the country, using pressurized systems of irrigation (drip, microsprinkling or sprinkling), which include an area of 2 686,4 ha and benefit 2023 families who mainly cultivate vegetables, root crops, tubers, ornamental plants and fruits.

Drinking Water and Water Quality. The human water consumption and water sanitation is leaded by the Instituto Costarricense de Acueductos y Alcantarillados (AyA) which also is the largest national potable water system operator. There are other operators such as municipalities, the Empresa de Servicios Públicos de Heredia (ESPH S.A.), the Administrative Committees of Rural Water Systems (CAARs), Community Water Supply Systems (ASADAS) and some private organizations. By 2010, a total of 2302 water supply systems were in place (Astorga, 2010). The percentage of water systems with acceptable potable drinking water quality for each operator was: $98,9 \%$ for AyA, 69,7\% for CAARs/ASADAS, 79,4\% for municipalities and 100\% for ESPH (Astorga, 20 I0). According to Arias $(201 \mathrm{I})$, by 2010 the coverage of potable quality water nation wise increased to $89,5 \%$ and the water coverage for water human consumption is 98.7\% of the total population. The provinces that are receiving the lowest percentage of non-potable water are San José (3,9\%), Guanacaste (10,3\%) and Puntarenas (11,3\%) and the provinces with the highest percentage of non-potable water are Alajuela ( I I,8\%) and Limón (12,3\%). According to Aguilar et al (2004) on the average human water consumption in Costa Rica is about 250 liters/day/ person assuming 50\% efficiency in the water pipes distribution system. Hence by 2005 the estimated annual water consumption was $18,7 \mathrm{~m}^{3} / \mathrm{s}$ (assuming a population of 4309400 inhabitants).

A major risk of groundwater pollution in the Central Region is the tendency of several aquifers to exceed the maximum allowable concentration of $50 \mathrm{mg} / \mathrm{l}$ of nitrate by overuse of agrochemical (mainly nitrogen fertilizer) and the uncontrolled used of septic tanks. Among these aquifers are the Barba and Colima Superior Aquifers (Losilla et al., 200I, OPS, 2003), as well as some wells located in Moravia, Tibás, San José, and aqueducts of Paraíso, San Isidro de Atenas and Bolsón-Ortega in Nicoya (MINSA, 2003). There also had been incipient processes of saline intrusion in the aquifer Brasilito in Guanacaste (Calderón et al., 2002) and since 200 I there had occurred leaking accidents from gasoline stations that had resulted in the filtration of hydrocarbons in important aquifers (Astorga, Y. 2009). 


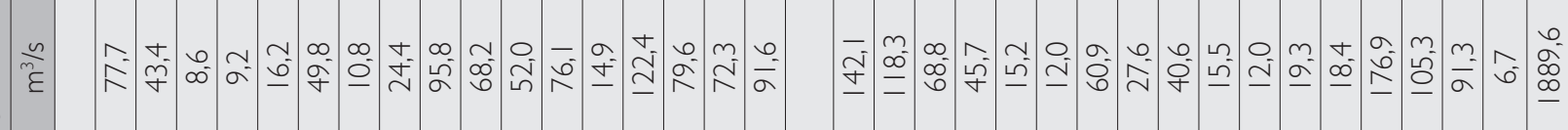

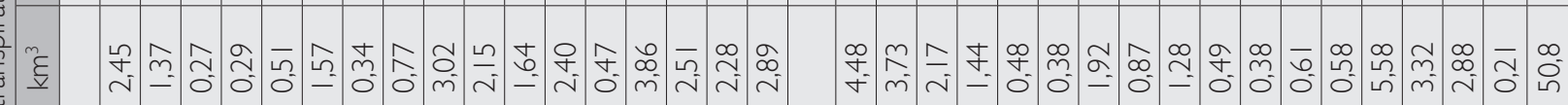
年

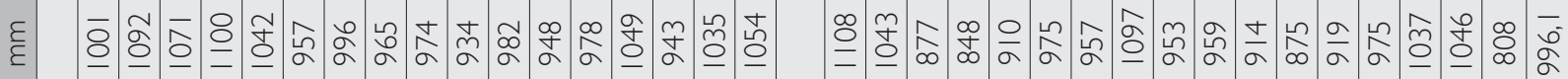

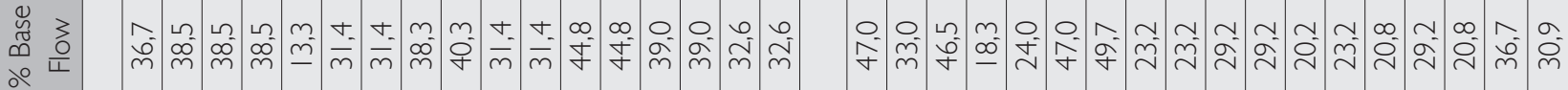

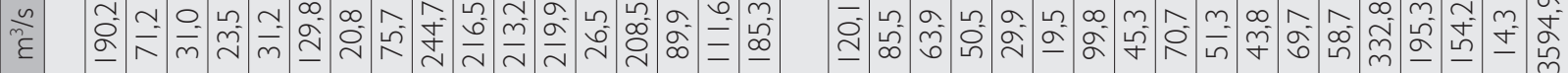

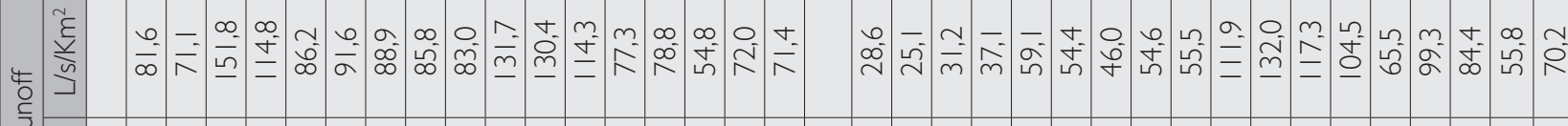

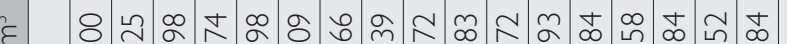

হ 을

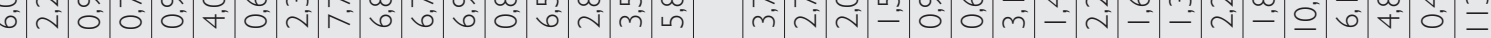

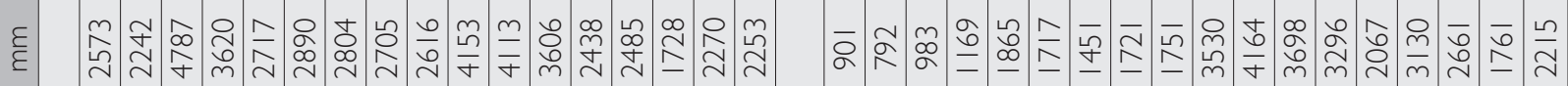

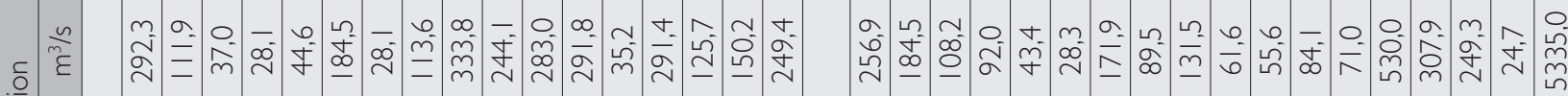

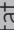

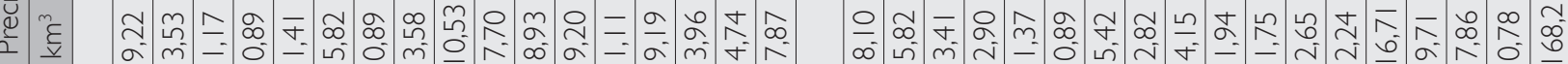

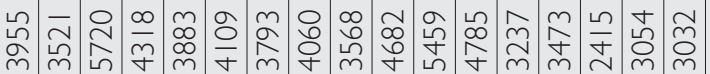

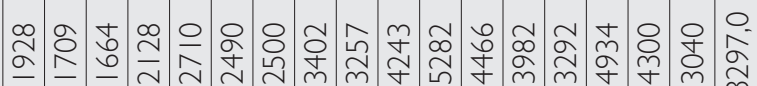

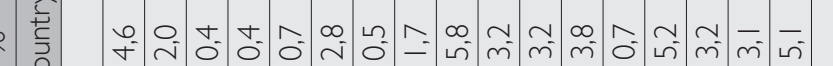

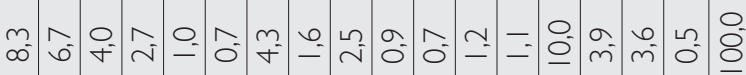

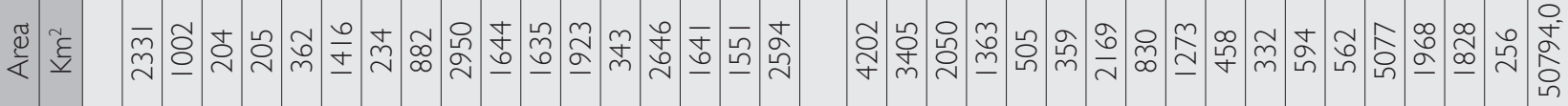

\section{气ิ}

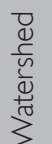

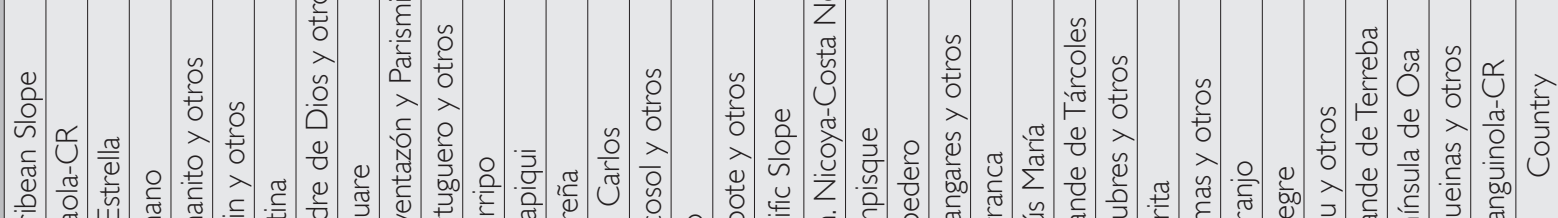

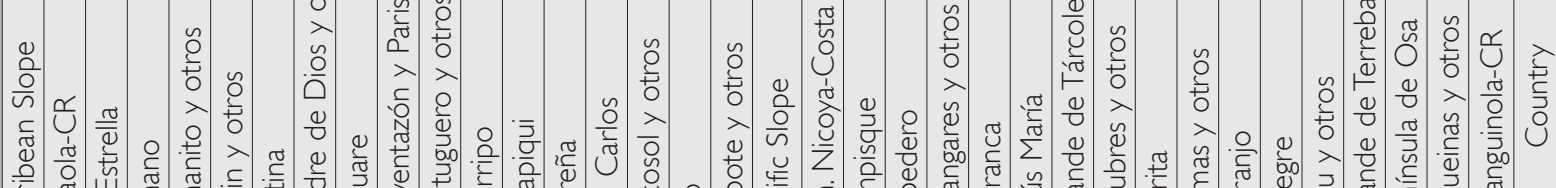

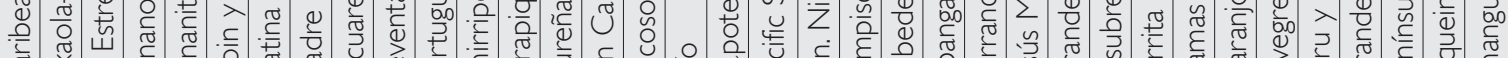

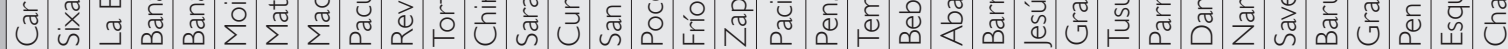


In relation with the waste water sanitation by 2008 only $25,6 \%$ of the population was connected to sewage systems but only 3,6\% with appropriate treatment, which means that most of the sewage goes directly to the streams, being the Grande de Tárcoles Watershed the most polluted. Then about 70.7\% of the houses have septic tanks and 3.7\% latrines (Astorga, 2009). For this reason the government is investing USA $\$ 270$ million in a sewage collector system and treatment plants to serve I 144000 inhabitants of the metropolitan area of San Jose by year 2015. Then a second phase is planned to continue in order to connect the cities of Heredia and Alajuela with an additional population of I 600000 .

River Navigation. There are about $812 \mathrm{~km}$ of natural and artificial channels are used for small craft navigation; $702 \mathrm{~km}$ correspond to the Caribean Slope and $110 \mathrm{~km}$ to the Paficic Slope (MOPT, I98I). It is estimated that about $104,5 \mathrm{~m}^{3} / \mathrm{s}$ of minimum flow is required for this activity (Jovel, 1974).

Freshwater aquaculture. According to FAO (20II) most of the fish farming in Costa Ricas is base on Trout - Oncorhynchus sp (I I ha with 534 tonnes/ year) for domestic market and tilapia - Oreochromis sp (763 ha with 21000 tonnes/year) aimed at both domestic and international market. With regard to shrimp aquaculture (Litopeneaus sp), there are I 698 ha with an estimated production of 5265 tonnes/ year. There is also the farming of giant river shrimp
(Macrobrachium rosenbergii) in a very small scale (4 ha) with yields of about 5 tonnes/year. The number of producers has increased significantly, representing more than I I 46 aquaculture producers by 2004 , of which 68,41\% are producers of tilapia, 23,30\% trout producers and $8,3 \%$ freshwater shrimp producers.

Sectorial water utilization for years 2005 and 2020. Table 2 includes the best estimates of water used in Costa Rica in flows $\left(\mathrm{m}^{3} / \mathrm{s}\right)$ and volumes $\left(\mathrm{km}^{3}\right)$. In this case the data for year 2005 is based on fairly reliable sources; Comité Nacional de Hidrología y Meteorología (2002), Aguilar et al. (2004) and direct information from water related institutions. The estimates of water demand for year 2020 is a projection considering water use increases due to population, geothermal generation and economic growth of all sectors according to Aguilar et al. (2004). In the case of hydroelectricity it was taken into account flows of hydropower projects to be constructed between 2005 and 2020 such as: Pirris, Reventazón, Itiquis, Pacuare and Savegre.

As shown in Table 2 for 2005 Costa Rica uses 21,97 $\mathrm{km}^{3}$ (20\% of the available $113 \mathrm{~km}^{3}$ ). According to Aguilar et al (2004) in 2002 about 12\% of total water use came from underground sources while 88\% from surface sources. Groundwater sources were mostly used for human consumption and industry. By year 2020 there is a rapid growth of water use reaching an annual volume of $3787 \mathrm{~km}^{3}$ $\left(33,5 \%\right.$ of the available $\left.113 \mathrm{~km}^{3}\right)$, which reflects the significant increase in hydroelectricity generation.

Table 2. Costa Rica sectorial water utilization for years 2005 and 2020.

\begin{tabular}{|l|c|c|c|c|c|c|c|}
\hline \multicolumn{1}{|c|}{ Years } & \multicolumn{3}{c|}{2005} & \multicolumn{3}{c|}{2020} & Increase \\
\hline Units & $\mathrm{m}^{3} / \mathrm{s}$ & $\mathrm{Km}^{3}$ & $\%$ & $\mathrm{~m}^{3} / \mathrm{s}$ & $\mathrm{Km}^{3}$ & $\%$ & $\%$ \\
\hline Geo-Termic generation & 0,21 & 0,01 & 0,03 & 2,25 & 0,07 & 0,03 & 967 \\
\hline Tourism & 3,49 & 0,11 & 0,50 & 7,93 & 0,25 & 0,49 & 127 \\
\hline Industry & 9,51 & 0,30 & 1,37 & 18,07 & 0,57 & 1,33 & 90 \\
\hline Agro-Industry & 15,85 & 0,50 & 2,28 & 18,07 & 0,57 & 2,22 & 14 \\
\hline Human comsuption & 18,70 & 0,59 & 2,68 & 22,73 & 0,72 & 2,62 & 22 \\
\hline Irrigation & 147,75 & 4,66 & 21,21 & 187,91 & 5,93 & 20,68 & 27 \\
\hline Hydroelectricity & 501,00 & 15,80 & 71,93 & 944,00 & 29,77 & 72,64 & 88 \\
\hline Total water use & 696,51 & 21,97 & 100,00 & 1200,97 & 37,87 & 100,00 & 72 \\
\hline
\end{tabular}

Notes for estimation 2005: Geothermic generation $150 \mathrm{GWh}$, human consumption for 4,309.400 inhabitants, irrigation for 103,000 has and total hydroelectricity generation equals I $408 \mathrm{MW}$.

Notes for estimation 2020: Geothermic generation 1600 GWh, human consumption for 5,237.700 inhabitants, irrigation for 131,000 has and total hydroelectricity generation equals $2698 \mathrm{MW}$. 
Current political, legal and institutional Framework

Historical Background. Historically water has been a valuable natural resource for social, economic and cultural development, but its relative abundance has created the idea that it is an unlimited renewable natural resource. Unfortunately during the last decades it has been notorious that the management of water resources is misguided, resulting in social and environmental conflicts with very serious consequences for public health and ecosystem integrity. The following is a brief historical description of the evolution of water resources legal and institutional framework based on Jiménez (1973), Botey (2002), Comité Nacional de Hidrología y Meteorología (2002) and Alvarado (2003).

From Costa Rica independence from Spain in 1821 to the enforcement of the Constitution in 1848 , there was no legislation to regulate water use. Until then, the legislation was under the influence of the Spanish legal tradition that allowed the use and distribution of water in a casual way. During 1849 1870 the country experienced a process of institutionalization of authority which was reflected in the Constitution of $187 \mid$ with a strong influence from the French Declaration of Human Rights. During these years many legal contributions were declared such as: The Civil Code, the Civil Procedure Code, the Executive Trial Act, the Public Prosecutor's Office Act, the Civil Registry Law, the Courts Law and the Notaries Law. Then the fast growing industry of cultivation and exportation of coffee made the shift from an economy of self-sufficiency model to a model of agrarian capitalism; all this change fueled by the State Chief Braulio Carrillo.

After the liberal reforms of the 1880 decade, a law was necessary to put the water resources in harmony with the coffee export model of the time. It is in this context that was established the Water Act No. Xl of May $26^{\text {th }}$, I 884, which introduces the concept of water as a public good and therefore its use is subject to prior authorization from the state. Afterward the Hydraulic Forces Act No. 14 of October $3 \mathrm{l}^{\text {st }}, 1910$ and its corresponding regulatory decree No. 2 of September $16^{\text {th. }} 191$ I, came to control water withdraw concessions for hydropower generation, removing the municipalities authority to grant water concessions and transferring this power to the Executive Branch. Then in 1928 it was established the National Electricity Service (SNE) by the Act No. 77 which served as the regulatory water use office.

Since hydroelectric generation was developed by foreign monopolistic companies in Central American and Caribbean area, a group of citizens formed the so called National Civic League during the 1920's decade. This movement fought for the nationalization of electricity, which led to a new National Electricity Service Act (SNE), No. 258, August $18^{\text {th }}$, 194I and replaced The Hydraulic Forces Act of 1910. This change transferred the power to grant concessions for water generation to the Office of Geology. This led to the nationalization of electricity and thus the foundation of the National Electricity Company in 1941 (CNFL). During that same year the Drinking Water Act No. 16 had been approved.

In those years the national economy followed an agro-export model based on coffee, bananas, sugar cane and cocoa production, with an agro-industry sector: sugar mills, coffee mills, textile factories, ice and alcoholic beverages plants. Also agriculture irrigation and hydroelectric generation increased, which were not covered in the previous Water Act of 1884. In this way and after 58 years, the scene was ready to issue the Water Act No. 276 of August $27^{\text {th }}, 1942$, which is currently in force. In 1949 it was created the Costarrican Electricity Institute (ICE) with the mission to develop, execute, produce and sell electric utilities and telecommunications. With the creation of ICE initiated a process of infrastructure investment and generation of valuable hydro-meteorological information. In 1953 it was established a General Water Law No. 1634 which replaced the National Electricity Service Act of 194I. All issues related with drinking water were finally complemented with the establishment of the Costa Rica Institute of Water and Sewerage (AyA) Act No. 2726 of April 14 $4^{\text {th }}, 1961$, reinforced by Law No. 3668 of March 16 th, 1966 and amended by Law No. 5915 of July 12 $2^{\text {th }}$, 1976, which gradually unified the management of potable water supply and sewage management in a single institution, limiting the previously management by municipalities and community boards under the supervision of the Ministry of Health.

In 1973 the Constitutive Act No. 5438 of the National Groundwater Service (SENAS) was promulgated in response to the increasing use of 
groundwater. The SENAS was also created to promote hydrogeology research and to advise state agencies on issues related to groundwater management and conservation. During the seventies, the exportation of non-traditional agricultural products became important and turned water into a strategic input. Thus the Ministry of Agriculture and Livestock (MAG) launched a national irrigation program that initiated with the "Itiquís and La Garita" Irrigation District located in the Province of Alajuela, under the Decree No. 2857 of February 26 $6^{\text {th }}, 1973$ and the Law of Itiquís River Irrigation Project No. 6040 January $18^{\text {th }}, 1977$.

In 1982, the SNE's Department of Irrigation conceived a project to reuse turbined water from the Arenal's Hydroelectric Project, a transbasin project transferring water flows $\left(100 \mathrm{~m}^{3} / \mathrm{s}\right)$ from the Caribbean to the Pacific slope to provide water for irrigation to the lower Tempisque basin. Hence, in 1983 the Law of the National Ground Water, Irrigation and Drainage Agency (SENARA), No. 6877 was promulgated. Then in 1995 it was promulgated the Environment Law No 7554, which states that water is a public domain and that human consumption use is the priority over any other use. Followed on February $13^{\text {th }}, 1996$, it was promulgated a new Forestry Law No. 7575, regulating the use of public and private forest resources and including the protection of watersheds.

Current legal and institutional framework. Current institutional and legal framework related to water resources is discussed by Reynolds, J. et al. (1997), Comité Nacional de Hidrología y Meteorología (2002), Segura, O. et al. (2004), Aguilar, E. et al.(2004) and Astorga, Y. (2009) and it can be summarized as follows:

The Water Department of the Ministry of Environment, Energy and Telecommunications (MINAET) is the state agency in charge to control all public waters and to grant or deny water concessions. According to Decree No. 26635 of 1997 the Water Department mission is to manage efficiently water resources throughout the country, ensuring sustainable development through its legal and rational management and providing an excellent service (Article 2). Nevertheless, it is well accepted that the fulfillment of this mission is almost impossible given the absence of enough human and financial resources for monitoring and surveillance of the concessions, as well as for planning and efficient management of canons.

On the other hand, there are state agencies with significant expertise using water as an input to provide basic services to society, among these: ICE, AyA, municipalities and the SENARA. In the area of public service delivery of water and sewage, as well as, treatment and sewage disposal there are 30 municipalities, the Public Service Company of Heredia (ESPH) and about I 800 Community Water Supply Systems (ASADAS) and Administrative Committees of Rural Water Systems (CAAR) of small rural water. Other organizations are: Regulatory authority for public services (ARESEP), National Meteorological Institute (IMN), MAG, the Land Court, the Health Ministry, the Comptroller General of the Republic, the Ombudsman, the National Institute of Housing and Urbanism (INVU), the National Community Development (DINADECO), the National Institute of Municipal Promotion and Advice (IFAM), the National Ports Institute (INCOP) and the four public universities.

The main problem with the existing institutional framework is that there is no a single institution responsible for planning and management of water resources. This problem has diluted the responsibility for administrative and technical aspect creating at the same time gaps in planning and research. An example of this is the dispersion of information on physical assessment and resource utilization, which is found in different formats, messy in some cases and nonexistent in others. Moreover, the agencies play different roles, either governing, supervisor and / or executing overlap in many functions resulting in low efficiency activities.

The most important laws governing the management of water resources in Costa Rica are the following:

- The "National Constitution of 1949", that establishes the sovereignty of water resources over the territory and declared them as a public asset.

- Water Law No. 276 of 1942 and its amendments that regulate all matters relating to water ownership and use.

- Law I634 of 1953, General Drinking Water Law declaring planning and implementation of water projects for the population of Costa Rica. 
- Law 2726 of 196I Law establishing the Costa Rica Institute of Water and Sewerage (AyA). There have been thirteen reforms to this law between 1966 and 1995.

- The Mining Code Law No. 6797 of 1982 that established that groundwater and surface waters are public and the State has the ownership and administration rights of them.

- The Environmental Law No 7554 of 1995, that states that water is of public domain, and that its conservation and use if for social interest. The law defines that water is a public utility and its use for human consumption has priority over any user.

- The Forestry Law No. 7575 of 1996 that regulates the state and private forests activities that may affect water resources. This law establishes protection of forest along the streams and that the State has an obligation to ensure watersheds protection.

According to Zeledón (2005) the Water Law No. 276 of 1942 is insufficient to meet the needs of national water sector due to increased demand, poor management, increasing environmental and social conflicts and problems of water access in terms of quantity and quality. Because of this since 200I, a draft Law on Water Resources had been submitted to the National Legislative Assembly. However this Law proposal (file 14585) was frozen in the National Legislative Assembly (Astorga, Y. 2009) and after 10 years the bill was removed from the list of projects under discussion. This law proposal basically pointed that the Water Department of MINAET had to become the national water resource authority, orders that each national watershed has a management plan with an advisory council and to develop a national water plan based on national watershed water balances. The proposed law also included two major funding mechanisms: a) a canon for the use of water calculated by on availability, consumed volume, demand, priority, administrative costs, social and productive value and b) a canon for sewage water disposal calculated by level of contamination and cost of conservation and restoration.

Recent Government Policy Strategy. In view of the importance of this natural resource and the lack of an acceptable legal and institutional framework, government established the National Water
Resources Plan (MINAET, 2008). This plan main goals has been to set the principles and guidelines for a National Water Policy focusing on three points: a) Maintain the role of water as an economic driver for the development of Costa Rica, according to the conditions imposed by the building of an equitable society and the constitutional right for a healthy and ecologically balanced environment, b) Consolidate, with economical sustainability criteria, the legal and institutional framework for an integrated management of water resources, laying the groundwork for a proper institutional coordination and encouraging more involvement of users, private sector and society in general and c) Develop and execute a water resources planning strategy for each national watershed by constructing monthly water balances and scenarios of water demand versus water availability.

\section{Conclusions and recommendations}

The privileged status of Costa Rica in terms of high availability water resources, has contributed to have a weak legal and institutional framework in this area, despite being one of the most important natural resources for the growth and development of country. During the last two decade, Costa Rica is experiencing a high demand of water resources by urbanization, industry, irrigation and hydroelectricity. On the top of this, future water demand is expected to rise exponentially in the coming decades. There exist ample water reserves but the widespread contamination of aquifers and streams by untreated wastewater, stormwater, unsustainable land use, and industrial effluents plus the incoming effect of climate change are real treats to the sustainability use of this strategic resource. Water legislation is old and very confusing, which creates major obstacles for sound management and conservation of water resources. There are at least 30 different laws that regulate the sector and hence a new modern water law is necessary for establishing acceptable water rates and sanctions and for promoting a good institutional coordination for water management and planning.

The path that Costa Rica has taken in addressing the issue of water resources has not been successful for two reasons: the first is that Costa Rica always has acted by reacting to problems as they come along and never by a precautionary approach for conservation and management, and the second reason 
is closely related to the time lag in the design and approval of new legislation and planning instruments. The proof of this is how outdated is the current water law, dating from 1942, and how difficult it has been to replaced it by a more modern and adequate one to face the new challenges and realities of the country. Consequently water management and planning is characterized by its fragmentation and dispersal among several institutions. Hence it is urgent to involved all water resources institutions to work together to design a comprehensive national model for water resource planning and management. To build such a model it is essential to adequately cover the following aspects: economic valuation of the resource to establish adequate rates or canons, establish a National Water Resources Authority to coordinate all sectors and institutions, development of a National Integrated Water Resources Plan supported by a revised and new water resources legislation.

\section{Acknowledgments}

This work was carried out with the aid of a grant from US National Science Foundation (Grant DEB 0516516) for support of LTREB: Dynamics of Stream Ecosystem Responses across Gradients of Reforestation and Changing Climate in a Tropical Dry Forest, a Study Conducted by Stroud Water Research Center with the collaboration of Instituto Tecnológico de Costa Rica. This work is also part of the Research Project: TROPI-DRY (Human, Ecological and Biophysical Dimension on Tropical Dry Forest) a collaborative research network sponsored by Inter-American Institute for Global Change Research (IAI) CRN II \# 021 which is supported by the US National Science Foundation (Grant GEO-0452325). This paper is also a partial requirement of the first author for her Doctoral degree, Programa de Doctorado en Ciencias Naturales para el Desarrollo (DOCINADE). We also acknowledge the financial and logistical support of the Vicerectoría de Investigación y Extensión del Instituto Tecnológico de Costa Rica.

\section{References}

Aguilar, E.; Ballestero, M.; Echeverría, J.; Espinoza, C.; Oreamuno, R.; Villalta, R. (2004). Diagnóstico. Primera etapa del plan de manejo integral del recurso hídrico: la estrategia nacional para el MIRH. Plan nacional de manejo integral del recurso hídrico. San José, Costa Rica. Ministerio del Ambiente y Energía de Costa Rica, 119 p.

Alvarado, D. (2003) Primeros 100 años de marco legal costarricense sobre recursos hídricos 1884 - 1984. Ministerio de Ambiente y Energía, San José, Costa Rica, 24 p.

Arias, A. (20II) Informe Final del Sector Agua Potable y Saneamiento. Ponencia preparada para el Decimoséptimo Informe Estado de la Nación, San José, Programa Estado de la Nación. 10 p.

Astorga, Y. (20 I0) Gestión del Recurso Hídrico y Uso del Agua. Ponencia preparada para el Decimosexto Informe Estado de la Nación. San José, Programa Estado de la Nación, 34 p.

Astorga, Y. (2009) Situación del recurso hídrico. Ponencia preparada para el Decimoquinto Informe Estado de la Nación. San José, Programa Estado de la Nación, 39 p.

Botey, A. (2000) Costa Rica. Desde las sociedades autóctonas hasta 19|4. Editorial de la Universidad de Costa Rica. San José, Costa Rica, 520 p.

Calvo-Alvarado, J. (1990). Water Resources Development in Costa Rica 1970-2000. Hydrological Sciences Journal 35: 185-196 pp.

CEPAL (Comisión Económica Para América Latina y El Caribe) (2005). Los Recursos Hídricos y la Agricultura en el Istmo Centroamericano. México. 77 p.

CINPE (Centro Internacional de Política Económica para el Desarrollo Sostenible) (2004). Situación del Agua en Costa Rica. Heredia, C.R Universidad Nacional. 20 p.

Comité Nacional de Hidrología y Meteorología (2002). Capital Hídrico y usos del Agua: Costa Rica. San José, Costa Rica. $30 \mathrm{p}$.

FAO (20I I). Aquaculture topics and activities. In: Departamento de Pesca y Acuicultura de la FAO. Roma. http://www. fao.org/fishery/countrysector/naso_costarica/es\#tcN90076 Accessed 3 Julio 2012.

Jiménez, M. (1973). Desarrollo Constitucional de Costa Rica. Editorial Costa Rica. San José, 278 p.

Jovel, R. (1974). Water Resources Development in Central America: 1970- 1980 Hydrol. Sci. Bull 19(4), 40 I-422.

Manso, P.; Stolz, W. and Fallas, JC. (2005). El régimen de la precipitación en Costa Rica. Ambientico p. 7-8

MINAET (Ministerio de Ambiente, Energía y Telecomunicaciones) (2008). Balances hídricos mensuales: oferta y demanda. Departamento de Aguas del Ministerio de Ambiente y Energía, BID, Banco Interamericano de Desarrollo e Instituto Mexicano de Tecnología del Agua. Informe Final. San José, Costa Rica. 172 p. 
MINAET (Ministerio de Ambiente, Energía y Telecomunicaciones) (2008). Plan Nacional de Gestión Integrada de Recursos Hídricos. Departamento de Aguas del Ministerio de Ambiente y Energía, BID, Banco Interamericano de Desarrollo. San José, Costa Rica. 140 p.

MINSA. (2003). Calidad del agua potable en Costa Rica: Situación actual y perspectivas. Serie Análisis de Situación de Salud; no. I3. San José, C.R. 40 p.

MOPT (Ministerio de Obras Públicas y Transportes) (I98|) Plan Nacional de Transportes. Volumen IV. Dirección de Planificación, MOPT, San José, Costa Rica.

Losilla M., Rodríguez H., Schosinsky G., Stimson J., and Bethune D.(200 I). Los acuíferos volcánicos y el desarrollo sostenible en América Central. Editorial Universidad de Costa Rica, $201 \mathrm{p}$.

OIRSA (Organismo Internacional Regional de Sanidad Agropecuaria) (2007). Descripción de Embalses de Costa Rica. Editorial OIRSA $42 \mathrm{p}$

OPS (Organización Panamericana de la Salud) (2003) Calidad del agua potable en Costa Rica: Situación actual y perspectivas. Serie Análisis de Situación de Salud; no. I3. San José, Costa Rica. 40 p
Reynolds, J. Rodríguez, H. and Chacón, E. (1997). Evaluación de los Recursos Hídricos en Costa Rica: Disponibilidad y Utilización. . Documento preparado para el Proyecto de Cuentas Ambientales, coordinado por el Centro Internacional de Políticas Económicas de la Universidad Nacional y el Centro Científico Tropical CCT/CINPE. Informe del Proyecto Cuentas Ambientales. Heredia, Costa Rica. $16 / p$.

Segura, O. Miranda, M. Astorga, Y. Solano, J. Salas, F. Gutiérrez, M. Dierckxsens, M. Céspedes, M. (2004). Agenda Ambiental del Agua en Costa Rica. Fundación CR-USA, Editorial Fundación Universidad Nacional (EFUNA), Heredia, Costa Rica, 192p.

UNESCO (2007). Balance hídrico superficial de Costa Rica. Período: 1970-2002. Programa Hidrológico Internacional (PHI). Oficina Regional de Ciencia para América Latina y el Caribe de la Organización de las Naciones Unidas par la Educación, la Ciencia y la Cultura Documentos Técnicos del PHI-LAC, N ${ }^{\circ} 10.49$ p.

Zeledón, JM. (2005). Proyecto de Ley del Recurso Hídrico. Ambientico no. 144 : I 5 